\title{
ŠIRDIES IR KRAUJAGYSLIŲ SISTEMOS FUNKCINIŲ RODIKLIŲ KAITA PAROS METU IR PER AEROBIKOS PRATYBAS
}

\author{
Sandra Bardauskienė, Ernesta Sendžikaitė, Algė Vitartaitė, Alfonsas Vainoras
}

Kauno medicinos universitetas, Kaunas, Lietuva

\begin{abstract}
Sandra Bardauskienė. Kauno medicinos universiteto (kineziologijos) magistrẻ. Mokslinių tyrimų kryptis — širdies ir kraujagyslių sistemos
\end{abstract} tyrimas.

\section{SANTRAUKA}

Tyrimo tikslas - ¿vertinti širdies ir kraujagysliu sistemos funkciniu rodikliu kaita paros metu ir per aerobikos pratybas. Buvo tiriamos 28 KMU studentes (22,6 \pm 0,43 m.), 2-3 kartus per savaitę (vidutiniškai 1,5 metu) lankančios sveikatingumo aerobikos pratybas.

Norint stebèti širdies ir kraujagysliu sistemos darba, buvo registruota elektrokardiograma (EKG) ir tirti šie dydžiai: $R$ dantelio amplitudè, ST amplitudè, JT intervalas, JT / RR santykio trukme ir ŠSD. Tirdami naudojome „, Cardio Scout“ (Vokietija -Lietuva) aparata su penkiais elektrodais, registruojančiais dvi iprastinés stebésenos metu naudojamas derivacijas, aparatas buvo tvirtinamas ant krütinès lastos. Ilgalaikis elektrokardiogramos registravimas vyko 24 valandas.

Tyrimai parodè, kad nakties metu širdies susitraukimu dažnis (ŠSD) buvo mažiausias, ryto, lyginant su vakaro, išliko

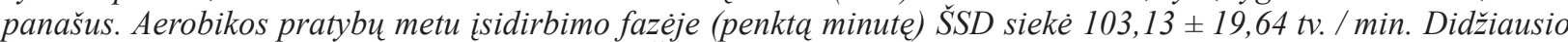
intensyvumo pratybu metu (trisdešimta minute) ŠSD sieke 153,78 16,14 tv. / min, atsigavimo metu (penkiasdešimta minute) $-101,03 \pm 14,47 \mathrm{tv}$ / min. R bangos amplitudès vidurkis per para (kai vyko aerobikos pratybos) ir aerobikos pratybu metu buvo visiškai vienodas, tačiau standartinis nuokrypis patikimai skyrèsi $(p<0,05)$. JT intervalo ir ST amplitudès reikšmès didžiausio intensyvumo aerobikos pratybu fazèje statistiškai patikimai skyrèsi nuo issidirbimo ir atsigavimo faziu $(p<0,05)$. JT intervalas patikimai buvo ilgiausias nakties metu, trumpiausias - maksimalaus krūvio metu, o standartinis nuokrypis mažiausias nakties metu $(p<0,05)$. ST amplitudè patikimai didèjo krūvio metu, o esant ramybès būsenai mažèjo. Per parq registruotos ST amplitudès buvo panašios ( $p>0,05)$. Analizuojant $J T$ / RR intervalu santykio reikšmès per aerobikos pratybas j̇vairiose treniruotès fazèse ir paros metu buvo panašios $(p>0,05)$, tačiau JT / RR intervalu santykis maksimalaus aerobinio krūvio metu, palyginus su paros rodikliais, buvo patikimai didesnis.

Raktažodžiai: širdies ir kraujagysliu sistema, funkciniai rodikliai stebèsenos metu, elektrokardiografija, aerobikos pratybos.

\section{IVADAS}

Š irdies ir kraujagysliu sistemos ( ̌́KS) ligu plitimas skatina kurti naujus kompleksinius diagnostikos metodus norint ivertinti žmogaus, kaip dinaminès sistemos, funkcinę būklę ir tirti sveikatos stiprinimo procesą. Tinkamai parinktas ir adekvačiai dozuojamas fizinis krūvis gali sumažinti ŠKS ligų simptomus arba neleisti šioms ligoms atsirasti, gerinti fizinio krūvio toleravimą ir gyvenimo kokybę (Feigenbaum, Pollock, 1999; Vasiliauskas ir kt., 2000).

Viena iš populiariausiu fizinio aktyvumo formu tarp moteru yra sveikatingumo aerobika. Ivairiu fiziniu pratimu taikymas aerobikos pratybose lavina daugeli žmogaus fizinių ypatybių (aerobini darbingumą, raumenu jẻgos ištvermę, lankstuma, judesiu koordinacija). Visgi pastebimi tokiu fizinio aktyvumo formu trūkumai. Organizuojant grupines aerobikas pratybas, iškyla fizinio krūvio individualizavimo ir jo tinkamumo problemų. Neretai i sveikatingumo aerobikos grupes susirenka nevienodo amžiaus, fizinio pajègumo ir skirtingos sveikatos žmonès. Dažnai per tokias pratybas skiriami krūviai neatitinka organizmo funkciniu galiu, atsiranda sveikatos problemu, o treniruotems ypatingą žavesi ir emocini atspalvị suteikianti muzika sukelia daugybę teigiamų emocijų, kurios 
tarsi užtušuoja organizmo siunčiamus nuovargio signalus. Todèl svarbu nustatyti ir įvertinti tokiu pratybų sukeliamus pokyčius žmogaus organizme, rengti metodines rekomendacijas, kaip dozuoti fizini aktyvumą.

Pasaulyje atlikta nemažai tyrimų, kurių metu stebėtas aerobikos pratybu poveikis žmogaus organizmui. Tačiau dauguma jų atlikti su pulsometrais stebint ŠSD tik per aerobikos treniruotę (Laukkanen et al., 2001). Individualūs ŠSD rodikliai priklauso nuo reguliacinių sistemų veiklos, t. y. nuo simpatinės ir parasimpatinès nervų sistemos aktyvumo, nuo hormoninių reguliaciniu sistemų veiklos (Poderys, 2004).

Šio tyrimo naujumas yra tai, kad pasirinkta metodika leidžia registruoti širdies ir kraujagyslių sistemos rodiklių kaitą visą parą, aerobikos pratybu metu. Remiantis gautais rezultatais, galima vertinti fizinio krūvio (aerobikos pratybų) poveiki žmogaus organizmui visą parą.

Tyrimo tikslas - ivertinti širdies ir kraujagyslių funkcinių rodiklių kaitą paros metu ir per aerobikos pratybas.

\section{TYRIMO ORGANIZAVIMAS IR METODIKA}

Tiriamają imtị sudarè $28 \mathrm{KMU}$ studentès, 2-3 kartus per savaitę (vidutiniškai 1,5 metų) lankančios sveikatingumo aerobikos pratybas. Tirtų merginų amžiaus vidurkis $-22,6 \pm 0,43$ metur.

Ilgalaikis elektrokardiogramų registravimas atliktas naudojant „Cardio Scout“ (VokietijaLietuva) aparatą su penkiais elektrodais (jų svoris $-20 \mathrm{~g}$ ). Buvo registruojamos dvi iprastinès stebėsenos metu naudojamos derivacijos. Kiekvienai tiriamajai „Cardio Scout“ aparatas buvo pritvirtinamas ant krūtinès ląstos ryte apie 8-9 valanda, o per „Blue tooth“ ryši aktyvuojamas elektrokardiogramos įrašymas. EKG registruojama 24 valandas. Vertinti šie rodikliai: širdies susitraukimų dažnis, JT intervalo trukmè, R dantelio ir ST dislokacijos amplitudès, intervalų JT ir RR trukmių santykis (JT / RR).

Rodikliai registruojami tik tos paros metu, kada vyko aerobikos pratybos. Visus rodiklius stebejjome atsižvelgdami i tiriamujų veiklą ir mažiausią ŠSD reikšmę ryte, vakare ir naktị. Vertindami pasirinktus rodiklius, išskyreme tris aerobikos pratybu fazes: 1) issidirbimą (10 min trukmè, matavimai atlikti penktą minutę); 2) didžiausią intensyvumą (40 min trukmé, matavimai atlikti trisdešimtą minutę); 3 ) atsigavimą (matavimai atlikti penkiasdešimtą minutę). Isidirbimo fazejje tiriamosios atliko mažos apkrovos aerobinius judesius: ivvairius žingsnius ir jų derinius. Didžiausio intensyvumo fazeje taikème įvairiu judesių (su ir be polèkio fazių) junginius. Atsigavimo fazèje tiriamosios atliko tempimo pratimus. Atlikdami statistinę duomenu analizę, apskaičiavome kiekvienos tiriamosios nagrinëjamo rodiklio 10-ties vienas po kito fiksuojamų kardiociklų matavimo vidurkị ir standartinį nuokrypi $(\sigma)$, paskui — visos grupès rodikliu ir standartinio nuokrypio vidurkị.

Sudarème anketą, kurioje tiriamosios kas valandą nurodydavo savo veiklą.

Matematinè statistika. Statistinių duomenu analizė atlikta kompiuterinèmis SPSS 10.0 for Windows ir Microsoft Excel XP programomis. Buvo apskaičiuojamas kintamujų aritmetinis vidurkis, standartinis nuokrypis, standartine vidurkio iverčio paklaida. Vidurkių skirtumo patikimumas apskaičiuotas naudojant Stjudento t testą. Skirtumas su galima mažesne nei 0,05 paklaida buvo vertinamas kaip statistiškai patikimas $(\mathrm{p}<0,05)$.

\section{REZULTATAI}

Tiriamujų EKG rodiklių kaita paros metu pateikta 1 lentelèje. Rezultatai parodè, kad ryte ir vakare S̆SD reikšmès buvo beveik vienodos (ryte $-79,98 \pm 10,35$ tv. / min, vaka$\mathrm{re}-80,15 \pm 11,53 \mathrm{tv}$. / min $(\mathrm{p}>0,05)$. Pastebèta, kad ŠSD naktị buvo mažiausias, t. y. $64,99 \pm 9,62$ tv. / min ir statistiškai patikimai skyrèsi nuo registruoto ryte ir vakare $(\mathrm{p}<0,05)(1 \mathrm{pav}$.). Nakties metu nustatytas mažesnis standartinis nuokrypis. $\mathrm{R}$ dantelio amplitudès vidurkis svyravo nedaug. Didžiausias standartinis nuokrypis buvo dieną, o naktị mažiausias $(\mathrm{p}<0,05)$. JT / RR intervalų santykis išliko panašus, tačiau buvo linkęs trumpèti nakti. EKG JT intervalo trukmè registruota ryte $262,29 \pm 34,61 \mathrm{~ms}$, vakare $-257,96 \pm 34,13 \mathrm{~ms}$, nakti $-310,43 \pm 38,46 \mathrm{~ms}$. Naktinio rodiklio reikšmė statistiškai patikimai skyrèsi $(p<0,0001)$ nuo rytinio ir vakarinio JT intervalo ( 2 pav.). Pastebejome patikimą šio dydžio standartinio nuokrypio sumažejimą nakties metu, kai JT intervalas buvo ilgiausias. ST amplitudès reikšmių kaita paros metu buvo panaši $(\mathrm{p}>0,05)$.

Elektrokardiogramos rodiklių vidurkiu ir standartinių nuokrypių vidurkių kaita aerobikos 


\begin{tabular}{|c|c|c|c|c|c|c|c|}
\hline $\begin{array}{l}\text { Paros } \\
\text { metas }\end{array}$ & $\begin{array}{c}\text { Rodikliu } \\
\text { vidurkiai ir } \\
\text { nuokrypiai }\end{array}$ & ŠSD, tv. / min & $\mathrm{R}, \mathrm{mV}$ & JT / RR & $\mathrm{JT}, \mathrm{ms}$ & ST, mV & $\begin{array}{l}1 \text { lentelè. EKG rodikliai } \\
\text { skirtingu paros metu } \\
\text { Pastaba. } X^{\mathrm{r}}, X^{v}, X^{n}-\end{array}$ \\
\hline \multirow{2}{*}{ Rytas (r) } & $\overline{\mathrm{X}} \pm \sigma$ & $79,98 \pm 10,35$ & $2,71 \pm 1,16$ & $346,28 \pm 42,62$ & $262,29 \pm 34,61$ & $0,04 \pm 0,06$ & \multirow{6}{*}{$\begin{array}{l}\text { Pastaba. } X^{\mathrm{r}}, \mathrm{X}^{\mathrm{v}}, \mathrm{X}^{\mathrm{n}}- \\
\text { dydis skiriasi nuo reikš- } \\
\text { mės ryte, vakare ar nakti } \\
(\mathrm{p}>0,95) . \mathrm{M}_{\sigma}-\text { asme- } \\
\text { nu standartiniu nuokry- } \\
\text { piu vidurkis. * - kie- } \\
\text { kvieno ciklo rodikliu } \\
\text { išsibarstymas nebuvo } \\
\text { skaičiuojamas. }\end{array}$} \\
\hline & $\mathrm{M}_{\sigma} \pm \sigma$ & $4,04 \pm 2,13$ & $0,13 \pm 0,09$ & * & $15,54 \pm 8,2$ & $0,03 \pm 0,04$ & \\
\hline \multirow{2}{*}{ Vakaras (v) } & $\overline{\mathrm{X}} \pm \sigma$ & $80,15 \pm 11,53$ & $2,85 \pm 1,21$ & $339,97 \pm 36,03$ & $257,96 \pm 34,13$ & $0,07 \pm 0,1$ & \\
\hline & $\mathrm{M}_{\sigma} \pm \sigma$ & $3,87 \pm 2,4$ & $0,16^{\mathrm{n}} \pm 0,1$ & * & $15,2 \pm 6,57$ & $0,03 \pm 0,04$ & \\
\hline \multirow[t]{2}{*}{ Naktis (n) } & $\overline{\mathrm{X}} \pm \sigma$ & $64,99^{\mathrm{rv} v} \pm 9,62$ & $2,75 \pm 1,05$ & $332,49 \pm 41,11$ & $310,43^{\mathrm{rv}} \pm 38,46$ & $0,03 \pm 0,6$ & \\
\hline & $\mathrm{M}_{\sigma} \pm \sigma$ & $3,24 \pm 1,94$ & $0,1^{\mathrm{r}, \mathrm{v}} \pm 0,04$ & * & $12,62^{\mathrm{r}, \mathrm{v}} \pm 4,45$ & $0,03 \pm 0,03$ & \\
\hline
\end{tabular}

\begin{tabular}{|l|c|c|c|c|c|c|}
\hline \multirow{2}{*}{$\begin{array}{c}\text { Aerobikos } \\
\text { pratybos }\end{array}$} & $\begin{array}{c}\text { Rodiklių } \\
\text { vidurkiai ir } \\
\text { nuokrypiai }\end{array}$ & ŠSD, tv. / min & $\mathrm{R}, \mathrm{mV}$ & $\mathrm{JT} / \mathrm{RR}$ & $\mathrm{JT}, \mathrm{ms}$ & $\mathrm{ST}, \mathrm{mV}$ \\
\hline $\begin{array}{l}\text { Isidirbimo } \\
\text { fazé (i) }\end{array}$ & $\overline{\mathrm{X}} \pm \sigma$ & $103,13 \pm 19,64$ & $2,76 \pm 1,22$ & $347,87 \pm 104,87$ & $227,89 \pm 35,12$ & $0,1 \pm 0,1$ \\
\cline { 2 - 7 } & $\mathrm{M}_{\sigma} \pm \sigma$ & $3,91 \pm 1,7$ & $0,2 \pm 0,11$ & $*$ & $20,19 \pm 10,14$ & $0,07 \pm 0,07$ \\
\hline $\begin{array}{l}\text { Didžiausio } \\
\text { intensyvumo } \\
\text { fazé (d) }\end{array}$ & $\overline{\mathrm{X}} \pm \sigma$ & $153,78^{\mathrm{i}, \mathrm{a}} \pm 16,14$ & $2,78 \pm 1,21$ & $417,21^{\mathrm{i}, \mathrm{a}} \pm 55,72$ & $163,96^{\mathrm{i}, \mathrm{a}} \pm 28,8$ & $0,21^{\mathrm{i}, \mathrm{a}} \pm 0,16$ \\
\cline { 2 - 7 } & $\mathrm{M}_{\sigma} \pm \sigma$ & $2,5 \pm 1,65$ & $0,3^{\mathrm{i}, \mathrm{a}} \pm 0,12$ & $*$ & $20,15 \pm 7,79$ & $0,15^{\mathrm{i}, \mathrm{a}} \pm 0,11$ \\
\hline $\begin{array}{l}\text { Atsigavimo } \\
\text { fazè (a) }\end{array}$ & $\overline{\mathrm{X}} \pm \sigma$ & $101,03 \pm 14,47$ & $2,82 \pm 1,09$ & $353,66 \pm 48,14$ & $213,15 \pm 35,52$ & $0,08 \pm 0,1$ \\
\cline { 2 - 7 } & $\mathrm{M}_{\sigma} \pm \sigma$ & $2,77 \pm 1,41$ & $0,15 \pm 0,1$ & $*$ & $18,73 \pm 8,71$ & $0,06 \pm 0,06$ \\
\hline
\end{tabular}

2 lentelè. ŠKS rodikliai aerobikos pratybų metu (aritmetinis vidurkis \pm standartinis nuokrypis, $\overline{\mathbf{x}} \pm \sigma$ )

Pastaba. $X^{\mathrm{i}}, \mathrm{X}^{\mathrm{d}}, \mathrm{X}^{\mathrm{a}}$ - dydis skiriasi nuo reikšmès isidirbimo, didžiausio intensyvumo ar atsigavimo fazèse $(p>0,95)$. $\mathrm{M}_{\sigma}$ - asmenų standartinių nuokrypiu vidurkis. * - kiekvieno ciklo rodikliụ išsibarstymas nebuvo skaičiuojamas.
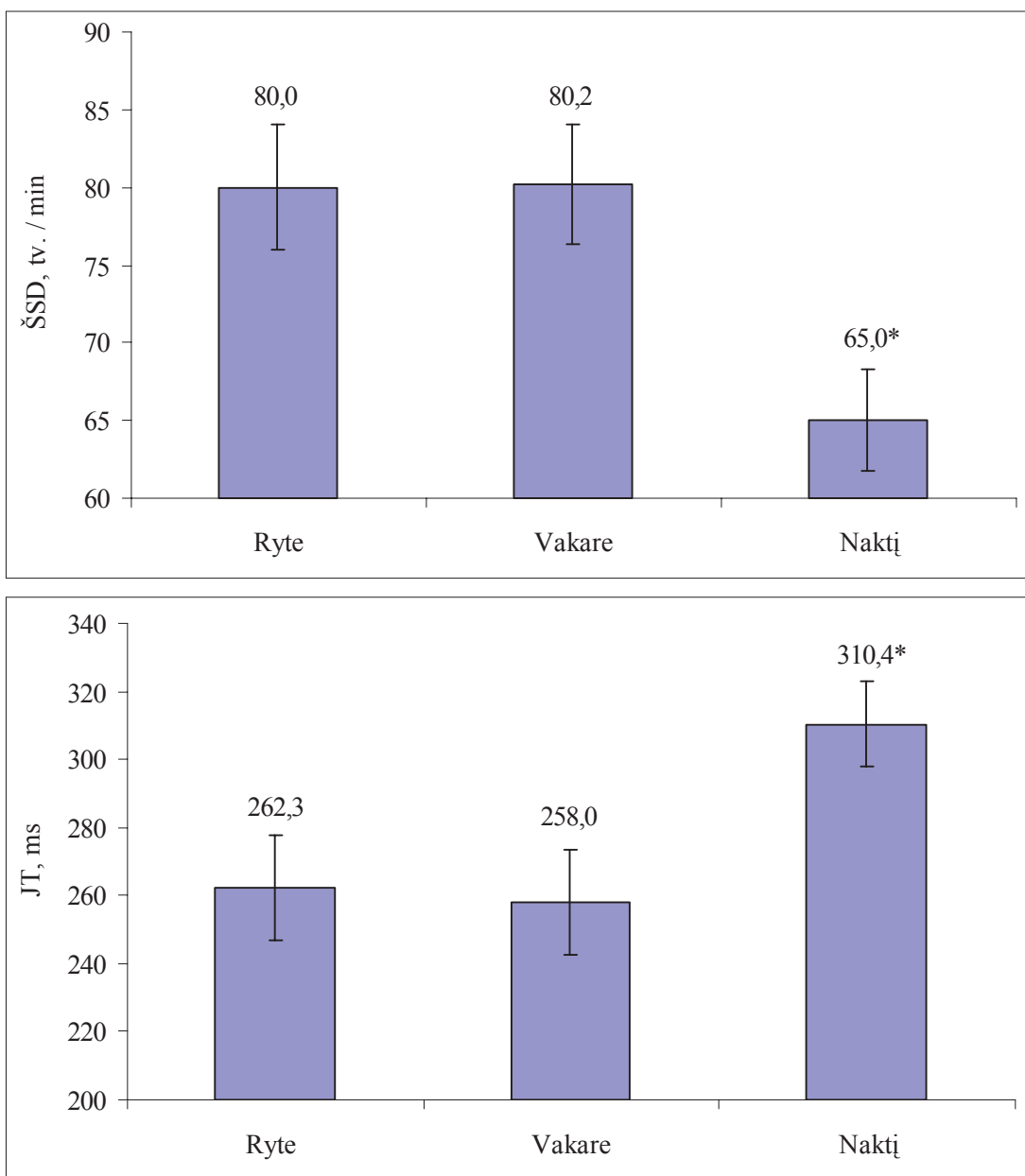

1 pav. ŠSD kaita paros metu

Pastaba. * $-\mathrm{p}<0,05$, lyginant naktini su rytiniu ir vakariniu rodikliu.

2 pav. JT intervalo kaita paros metu

Pastaba. $*-p<0,05$, naktinis JT intervalas skyrèsi nuo intervalu, registruotų ryte ir vakare. pratybu metu pateikta 2 lenteleje. Analizuodami EKG rodiklių kaitą aerobikos pratybų metu nustatėme ŠSD rodiklio statistiškai patikimą skirtuma didžiausio intensyvumo fazèje $(\mathrm{p}<0,0001)$, lygi- nant ji su isidirbimo ir atsigavimo fazèmis (isidirbimo fazèje $-103,13 \pm 19,64$ tv. / min, didžiausio intensyvumo $-153,78 \pm 16,14 \mathrm{tv}$. / min, atsigavimo $-101,03 \pm 14,47 \mathrm{tv} . / \mathrm{min})(3 \mathrm{pav}$.$) .$ 
3 pav. ŠSD kaita aerobikos pratybų metu

Pastaba. * $-\mathrm{p}<0,05$, lyginant didžiausio intensyvumo su issidirbimo ir atsigavimo fazių reikšmèmis.

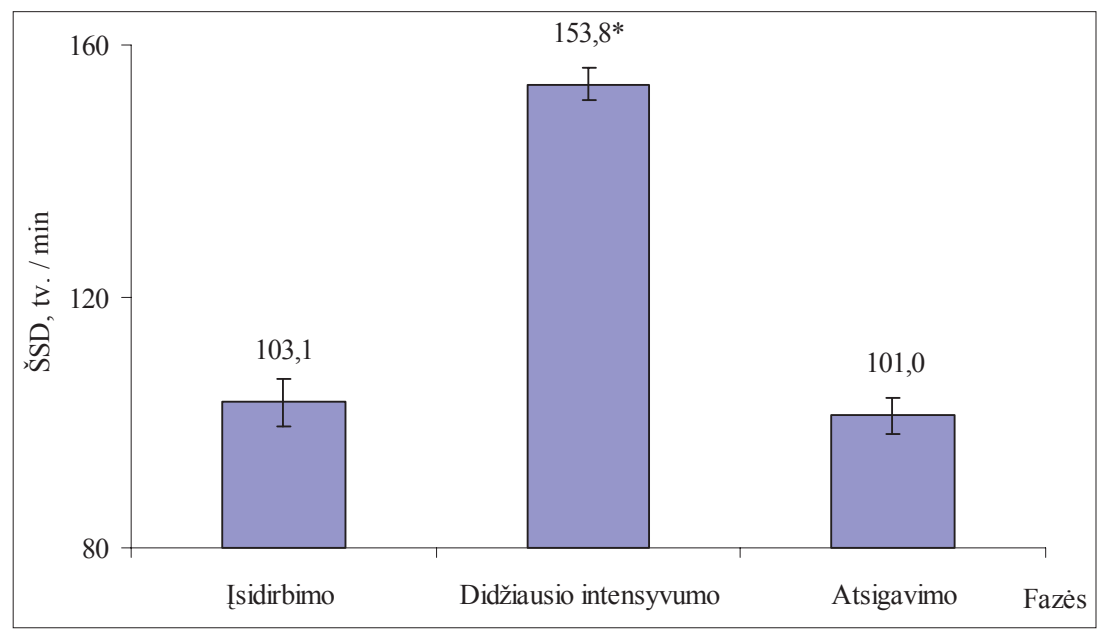

4 pav. JT intervalo kaita aerobikos pratybu
metu

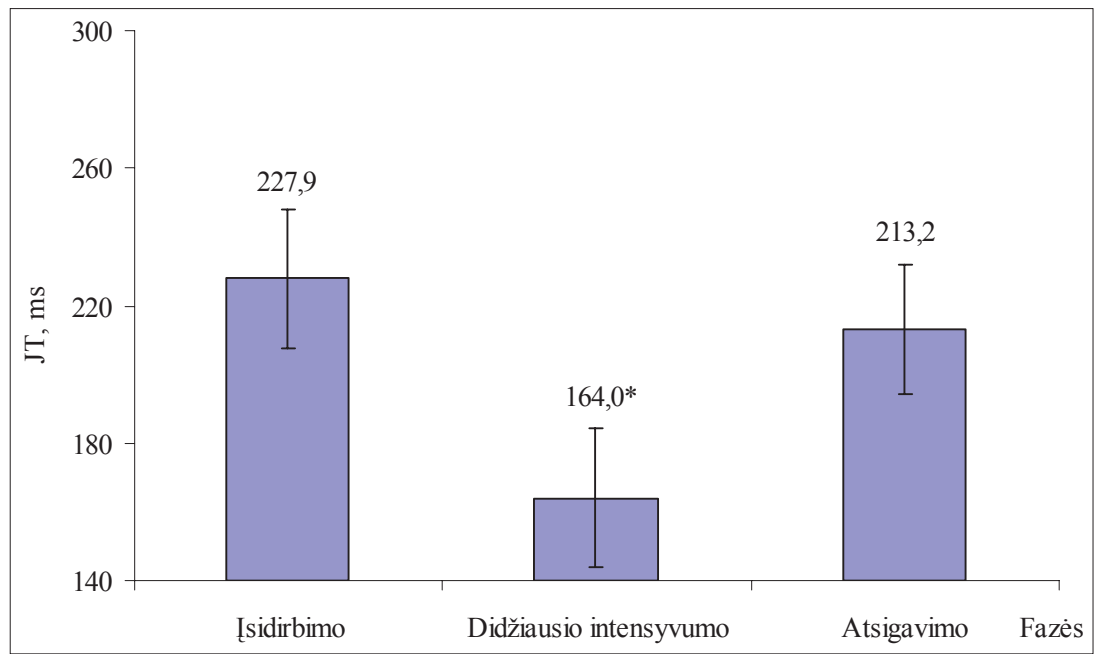

Pastaba. * $-p<0,05$, lyginant didžiausio intensyvumo su isidirbimo ir atsigavimo faziu reikšmèmis.

5 pav. ST amplitudès kaita aerobikos pratybų metu

Pastaba. * - p $<0,05$, lyginant didžiausio intensyvumo ir ịsidirbimo fazių reikšmes.

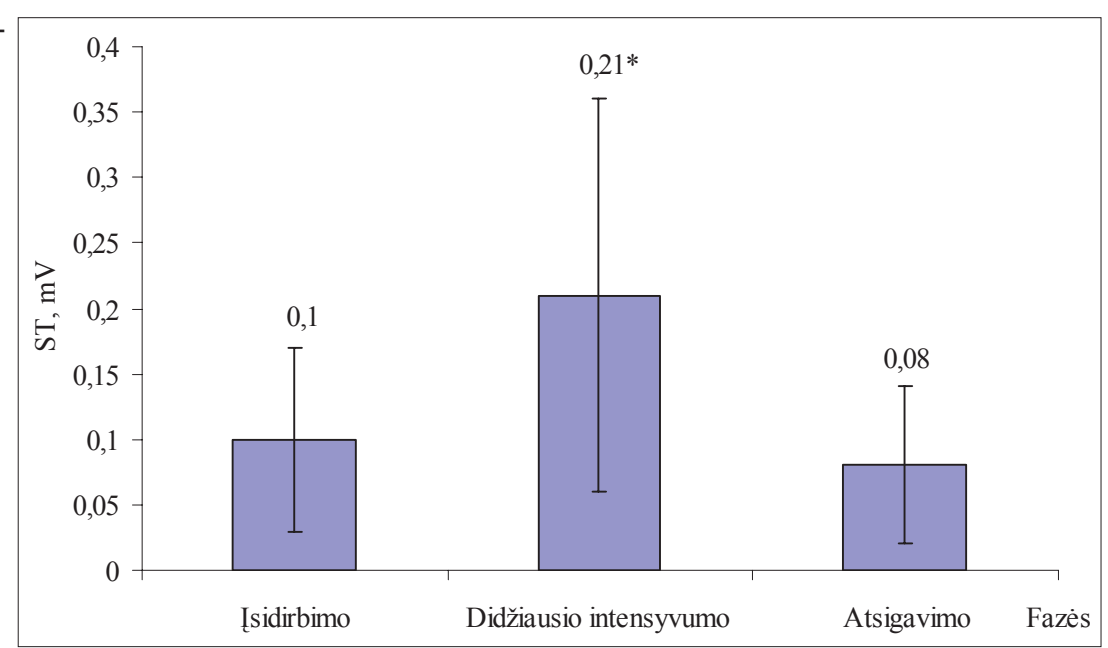

Standartinis nuokrypis šiais etapais beveik nepakito, tik pastebejjome jo mažèjimo tendencija (nuo 3,91 $\pm 1,7$ iki $2,5 \pm 1,65$ ) didžiausio intensyvumo fazejje ir širdžiai maksimaliai susitraukinejjant.

Nagrinèjant $\mathrm{R}$ dantelio amplitudès vidurkio kaitą krūvio metu, patikimo skirtumo nenustatyta, nors standartinis nuokrypis didžiausio intensyvumo fazèje buvo didžiausias (patikimai padidejo nuo $0,2 \pm 0,11$ iki $0,3 \pm 0,12$ ). Aerobikos pratybu metu vertinant tiriamujų JT / RR intervalų santyki, parodantị reguliacinès ir aprūpinamosios sistemos sąsają, pastebimas rodiklio vidurkio stabilumas.

Lyginant isidirbimo $(227,89 \pm 35,12 \mathrm{~ms})$ ir atsigavimo fazių JT intervalo reikšmes $(213,15 \pm 35,52 \mathrm{~ms})$ su didžiausio intensyvumo fazès JT intervalo reikšme $(163,96 \pm 28,8 \mathrm{~ms})$, nustatytas reikšmingas skirtumas $(\mathrm{p}<0,05)$. Isidirbimo ir atsigavimo fazèse JT intervalas išliko stabilus ( $\mathrm{p}>0,05)(4$ pav.). 
Didžiausio intensyvumo aerobikos pratybu metu ST amplitudès reikšmė buvo didžiausia $(0,21 \pm 0,16 \mathrm{mV}, \mathrm{p}<0,0001)$, lyginant su atsigavimo $(0,08 \pm 0,1 \mathrm{mV})$ ir isidirbimo fazèmis $(0,1 \pm 0,1 \mathrm{mV})(5$ pav. $)$.

\section{REZULTATŲ APTARIMAS}

Vienas plačiausiai ir išsamiausiai nagrinèjamų širdies ir kraujagyslių sistemos funkcinių rodikliu yra širdies susitraukimų dažnis. Paprastai, esant ramybès būsenai, sveiku jaunų ir vidutinio amžiaus žmonių širdies veiklą daugiausia reguliuoja parasimpatinè nervų sistema, kuri slopina širdies susitraukimų dažni ir mažina miokardo susitraukimo jègą. Dèl neigiamo chronotropinio parasimpatinès nervu sistemos poveikio, esant ramybès būsenai, širdis ekonomiškiau naudoja energinius resursus ir gali geriau adaptuotis prie fiziniu krūvių. Ramybės metu nesportuojančio žmogaus ŠSD svyruoja tarp 60-80 kartu per minutę (Skirius, 2005). Sportuojančių asmenų ŠSD ramybès sąlygomis sumažèja, išsivysto sportinè sinusinè bradikardija. Tyrimo metu širdies susitraukimo dažnis buvo mažiausias naktị, ramybès metu (1 lent.). Atskirų asmenų širdies susitraukimų dažnis priklausomai nuo fiziologinių organizmo savybiu svyravo nuo 42,4 iki $87,1 \mathrm{tv}$. / $\mathrm{min}$.

ŠSD kaita fizinio krūvio metu ir po jo parodo širdies funkcini pajègumą. ŠSD fizinio krūvio pradžioje dažniausiai padidèja iš karto. Pirmiausia susitraukimai padažnejja dèl simpatinès nervų sistemos aktyvumo padidejjimo. Tyrimo duomenys parodè, kad ŠSD vidurkis įsidirbimo metu sieke $103,13 \pm 19,64$ tv. / min. Didejant krūvio intensyvumui, ŠSD didèjo. Vertinant didžiausio intensyvumo fazèje pasiektą ŠSD nustatyta, kad vidutinè jo reikšmé, t. y. 153,78 $\pm 16,14$ tv. / min, atitiko $78,5 \%$ maksimalaus ŠSD (ŠSD ${ }_{\text {max }}=220$ - amžius) ir $68,1 \%$ rezervinio ŠSD (American College of Sports Medicine Position Stand, 1998). Tai leidžia teigti, kad fizinio krūvio intensyvumas atitiko priimtas rekomendacijas (55-90\% maksimalaus ŠSD arba $50-85 \%$ rezervinio ŠSD) ir neviršijo tiriamujų funkcinių galimybių.

Baigus fizinị krūvị, ŠSD iš karto mažèja. Po fizinio krūvio greičiau sumažèja ŠSD tu asmenų, kurių geresnis aerobinis darbingumas (Darr et al., 1988). Mažos ŠSD reikšmès nustatomos dèl aukšto aerobinio darbingumo. Ivertinus atsigavimo fazèje taikomų fiziniu pratimų krūvị, tiriamosios atliko raumenu statinio tempimo pratimus. Pastebejjome greita širdies dažnio atsigavima. Manome, kad buvo parinktas optimalus fizinis krūvis.

Aerobikos krūvio metu didejjant širdies susitraukimo dažniui, standartinis nuokrypis mažèjo, o jam retejant standartinis nuokrypis didejo (2 lent.). Stebėdami šio standartinio nuokrypio pokyčius nakti (kai širdies ritmas rečiausias) galejome tikètis didžiausio ŠSD rodiklių standartinio nuokrypio, tačiau nakti jis buvo reikšmingai mažiausias $(p<0,05)$. Didžiausio intensyvumo fazèje nustatème patikimai mažiausią JT intervalą. JT intervalas naktį buvo ilgiausias, o standartinis nuokrypis - mažiausias. Šio fakto aiškinimo prieinamoje literatūroje neaptikome. Ko gero, tai susiję su metabolinių procesų stabilizacija širdyje miego metu, tačiau pastebèti faktai reikalauja išsamesnių tyrimų ir naujų eksperimentu.

Nagrinedami R dantelio amplitudès rodikliu pokyčius per parą ir fizinio aktyvumo metu, patikimo skirtumo nepastebejome. Standartinis nuokrypis buvo mažiausias naktị tiriamosioms miegant, o maksimaliausias pastebėtas krūvio metu. Galima manyti, kad šiuos standartinio nuokrypio pokyčius gali lemti krūtinès varžos kaita, susijusi su kvėpavimu. Vadinasi, šio rodiklio analizè stebint gali leisti netiesiogiai vertinti ir asmens kvėpavimo funkciją fizinio aktyvumo metu, bet norint tai irodyti, reikia atlikti daugiau tyrimu. Dabartinėse komercinėse stebėsenos sistemose šio dydžio vertinimo metodikos neradome.

Geras širdies aprūpinimas krauju yra svarbus jos darbo našumo rodiklis. Organo aprūpinimo krauju intensyvumas nustatomas pagal jo metabolizmo lygi. Širdies metaboliniai pokyčiai yra susiję su JT intervalu (Vainoras ir kt., 1995; Gargasas ir kt., 1998). EKG JT intervalas atitinka širdies elektrinę sistolę ir jo pokyčiai susiję su miokardo metabolizmo intensyvumu. Minimali JT intervalo trukmè yra apie $160 \mathrm{~ms}$, maksimali $-360 \mathrm{~ms}$. Nors žinoma, kad treniruota, daugiau mitochondrijų turinti širdis geriau aprūpinama energija, o ramybès metu energiniai produktai eikvojami ekonomiškiau, tačiau tyrimo duomenys parodè, kad tiek santykinès (ryte ir vakare), tiek didžiausios (nakti) ramybès metu JT intervalo dydžiai nepriartèjo prie maksimalios reikšmès $(360 \mathrm{~ms})$. Manoma, taip atsitinka dèl to, kad širdis dalị savo pajègumo skiria organizmo sistemu gyvybingumui palaikyti ramybės sąlygomis.

Vertinant nagrinejjamo rodiklio kaitą aerobikos pratybu metu, pastebètas maksimalus miokardo 
metabolizmo suaktyvèjimas didžiausio intensyvumo fazèje. Šis faktas gali būti svarbus argumentas parenkant krūvio intensyvumą aerobikos pratybų metu. Jei nustatydami krūvio intensyvumą atsižvelgtume vien tik i Ł ŠSD, galètume manyti, kad organizmas dar turi rezerviniu galiu ji didinti. Tačiau JT intervalo reikšmès tam prieštarauja, todèl reikètų atsargiau vertinti maksimalaus ŠSD dydžius aerobinio krūvio metu. Atsigavimo fazejje JT intervalo trukmé vèl smarkiai $(\mathrm{p}<0,05)$ ilgejjo.

Net ramybès sąlygomis būtinesnis širdies nei kitu organu aktyvumas, todèl deguonies poreikis miokarde turi būti patenkinamas esant bet kuriam metabolizmo lygiui (Vainoras ir kt., 1995). Jeigu vainikinèmis širdies kraujagyslèmis tiekiama nepakankamai kraujo, tai pasikeitus metaboliniu procesu pusiausvyrai pakinta miocitu veikimo potencialai, o elektrokardiogramoje registruojami ST segmento amplitudès pokyčiai. ST segmento amplitudès nuokrypis nuo normos tiek ramybès, tiek fizinès veiklos metu laikomas požymiu, rodančiu tipišką miokardo hemodinamikos nepakankamumą ir galimą funkcinę išemiją. Atlikus tyrimą paaiškejo, kad paros metu registruotos ST amplitudès buvo panašios. Didžiausio intensyvumo fazejje ST amplitude smarkiai padidejo lyginant su ìsidirbimo faze $(p<0,0001)$. Ši pokyti, tikètina, paveikè hemodinamikos persiskirstymo ypatumai krūvio metu (Vainoras ir kt., 1995).

Organizmo širdies funkcijos mobilizacijos dydi gerai nusako elektrokardiogramos JT ir RR intervalu santykis - JT / RR (Vainoras, Jaruševičius, 1996; Poderys, 2004). Šio rodiklio kaita rodo, kaip greitai organizmas mobilizuoja savo galias prisitaikydamas prie krūvio. JT / RR intervalų santykis parodè, kaip ŠKS funkcija suaktyvėdavo dèl atliekamų aerobinių pratimų. Analizuojant EKG parametrus isidirbimo ir atsigavimo fazeje, nustatytas JT / RR intervalų santykis išliko panašus. Tą pati galima teigti apie ši rodikli pagal gautus šio santykio rezultatus paros metu. Ankstesni mokslininku darbai parodè, kad JT / RR santykis normalizuojasi greičiau nei kiti rodikliai (ŠSD, JT, ST R). Tai būtų galima paaiškinti: šis rodiklis (JT / RR) grižta i pradini lygit, nes po fizinio krūvio pirmiausia organizme būtina suderinti energinių medžiagų tiekimą atsigaunančioms sistemoms.

Gauti tyrimų rezultatai padeda suprasti širdies ir kraujagysliu sistemos greitosios adaptacijos prie fizinių pratimų dėsningumus. Tyrimų duomenys papildo sporto fiziologijos žinias apie žmogaus organizmo adaptacijos prie aerobinių pratimu specifiškumą, optimalių fizinių krūvių parinkimą, širdies ir kraujagysliu sistemos funkcinio pajègumo vertinima.

\section{IŠVADOS}

1. Paros metu.

Vertinant širdies ir kraujagysliu sistemos rodiklius paros metu, nustatytas mažiausias širdies susitraukimų dažnis ir ilgiausias JT intervalas nakti ( $p<0,0001)$, šių reikšmių standartinis nuokrypis mažiausias. JT / RR intervalo trukmès, ST amplitudès ir $\mathrm{R}$ dantelio amplitudès dydžio reikšmiu skirtumo paros metu nepastebèta.

2. Per aerobikos pratybas.

Nustatyta, kad širdies susitraukimų dažnio, JT intervalo, JT / RR intervalų santykio dydžiai ir ST amplitudès reikšmès didžiausio intensyvumo aerobikos pratybu fazejje statistiškai patikimai skyrèsi nuo isidirbimo ir atsigavimo fazių $(\mathrm{p}<0,05)$. $\mathrm{R}$ amplitude skirtingose fizinio krūvio fazèse buvo panaši, tačiau standartinis nuokrypis didžiausio krūvio metu patikimai padidejo. Greiti atsigavimo procesai liudija apie tinkamai parinktą fizinį krūvị, kuris nuodugniau gali būti vertinamas pagal JT intervalo pokyčius.

\section{LITERATŪRA}

American College of Sports Medicine Position Stand. (1998). The recommended quantity and quality of exercise for developing and maintaining cardiorespiratory and muscular fitness, and flexibility in healthy adults. Medicine and Science in Sports and Exercise, 30 (6), 975-991.

Darr, K. C., Basset, D. R., Morgan, B. J., Thomas, D. P. (1988). Effects of age and training status on heart rate recovery after peak exercise. American Journal of Physiology, 254, 2 (Pt 2), H 340-343.
Feigenbaum, M. S., Pollock, M. L. (1999). Prescription of resistance training for health and disease. Medicine and Science in Sports and Exercise, 31, 38-45.

Gargasas, L., Vainoras, A., Schvela, H. et al. (1998). JT interval changes during bicycle ergometry: Abstracts of $2^{\text {nd }}$ International Congress Polish Cardiac Society. Katovice, Poland (Sept., 4, P. 6, 153).

Laukkanen, R. M., Kalaja, M. K., Kalaja, S. P. et al. (2001). Heart rate during aerobic classes in women with different previous experience of aerobics. European 
Journal of Applied Physiology, 84, 64-68.

Poderys, J. (2004). Kineziologijos pagrindai. Kaunas: KMU. P. 189-204.

Skirius, J. (2005). Sporto medicina: funkcinès būklès medicinine kontrolè. Kaunas: LKKA. P. 137-146.

Vainoras, A., Jaruševičius, G. (1996). Veloergometrija (vykdymo metodai, kompiuterine analize, parametrai ir interpretacija): mokymo metodine priemone. Kaunas. P. 38.
Vainoras, A., Jasiūnas, V., Jaruševičius, G., Kukštaitė, E. (1995). Sveikų studentų širdies funkcijos adaptacinių ir reguliacinių galimybių ivvertinimas, tiriant automatizuota veloergometrijos sistema „Kaunas-Krūvis v.1.3“. Medicina, 31 (5): IV Lietuvos kardiologu suvažiavimas. Kaunas. P. 345.

Vasiliauskas, D., Marcinkevičienè, J., Aniulienè, E., Grižas, V. (2000). Širdies nepakankamumas ir fizinis krūvis. Kardiologijos seminarai, T. 6, 2, 22-28.

\title{
DYNAMICS OF CARDIOVASCULAR INDICES IN THE PERIOD OF 24 HOURS AND DURING AEROBIC CLASSES
}

\author{
Sandra Bardauskienė, Ernesta Sendžikaitė, Algė Vitartaitė, Alfonsas Vainoras \\ Kaunas University of Medicine, Kaunas, Lithuania
}

\begin{abstract}
The aim of this research was to study the changes of functional indicators of cardiovascular system in the period of 24 hours and during aerobic classes. Twenty eight female athletes ( $22.6 \pm 0.43$ years old), involved in aerobics exercise program (2-3 times per week for 1.5 years) participated in the study. The following electrocardiographic parameters were evaluated: R amplitude, ST amplitude, JT intervals, JT / RR ratio and heart rate (HR). All data were recorded using the specialized system "Cardio Scout" (Germany) with five electrodes recording two derivations. The system was fixed on the subject's breast and all data were recorded for 24 hours.

HR was significantly lower at night than in the morning or in the evening $(\mathrm{p}<0.05)$. Morning HR was similar to evening HR ( $p>0.05)$. HR values did not differ during the first five minutes of the exercise compared to the recovery phase $(p>0.05)$. However, the standard deviation of HR was heterogeneous during the 24 hour period. The amplitude of $\mathrm{R}$ wave during 24 hours (as well as during the aerobic classes) did not fluctuate, although the standard deviation changed significantly $(\mathrm{p}<0.05)$. The values of JT interval and STamplitude increased significantly during the highest intensity phase of the aerobic class and was higher than during the first five minutes and the recovery phase $(\mathrm{p}<0.05)$. The JT interval was the longest during the night and the shortest during the highest intensity phase; however, the standard deviation of JT interval was the least during the night time. The ST-amplitude increased significantly $(p<0.05)$ during the exercise, but decreased right after it. The ST amplitude in the period of 24 hours did not change significantly $(\mathrm{p}>0.05)$. There were no differences in the JT/RR intervals ratio during the different phases of the training session $(p>0.05)$ as well as in the 24 hour period ( $p>0.05)$. Nevertheless, JT / RR ratio during the highest intensity exercise phase was significantly higher compared to the 24 hour values $(p<0.05)$.
\end{abstract}

Keywords: cardiovascular system, functional indicators, ECG, aerobics.

Gauta 2006 m. gegužès 24 d.

Received on May 24, 2006

Priimta 2006 m. gruodžio $6 \mathrm{~d}$.

Accepted on December 6, 2006
Sandra Bardauskienè

Kauno medicinos universitetas

(Kaunas University of Medicine)

M. Jankaus g. 2, LT-50275 Kaunas

Lietuva (Lithuania)

$\mathrm{Tel}+37060402383$

E-mail bardauskiene@gmail.com 